\title{
Book Review: Overcoming Information Poverty: Investigating the Role of Public Libraries in the Twenty-First Century, Anthony McKeown
}

Mary Vasudeva

San Jose State University, mvasudeva03@yahoo.com

Follow this and additional works at: https://scholarworks.sjsu.edu/ischoolsrj

Part of the Information Literacy Commons, and the Scholarly Communication Commons

\section{Recommended Citation}

Vasudeva, M. (2017). Book Review: Overcoming Information Poverty: Investigating the Role of Public Libraries in the Twenty-First Century, Anthony McKeown. School of Information Student Research Journal, 6(2). https://doi.org/10.31979/2575-2499.060205 Retrieved from https://scholarworks.sjsu.edu/ ischoolsrj/vol6/iss $2 / 5$

This article is brought to you by the open access Journals at SJSU ScholarWorks. It has been accepted for inclusion in School of Information Student Research Journal by an authorized administrator of SJSU ScholarWorks. For more information, please contact scholarworks@sjsu.edu. 


\section{Book Review: Overcoming Information Poverty: Investigating the Role of Public Libraries in the Twenty-First Century, Anthony McKeown}

\section{Keywords}

information poverty, information literacy, public library

\section{About Author}

Mary Vasudeva is pursuing her MLIS at San Jose State University. She also teaches writing and critical thinking at San Ramon College. She has a Ph.D. in English from Bowling Green State University. Her other publications include co-editor of Between the Lines: South Asians on Postcolonialism and Identity and the "Writing Suggestions" sections for the forthcoming 12th edition of Asking the Right Questions: A Guide to Critical Thinking. 


\section{McKeown, A. (2016). Overcoming information poverty: Investigating the role of public libraries in the twenty-first century. Cambridge, MA: Chandos Publishing.}

McKeown's Overcoming Information Poverty: Investigating the Role of Public Libraries in the Twenty-First Century contributes a well-researched, compelling discussion of information poverty and how public libraries might respond given 21 st century challenges. He specifically addresses the question of how libraries can meet the information needs of their diverse communities given the significant changes in their structures while they grapple both with technological shifts and the larger role they are expected to play in addressing information literacy. McKeown proposes a three-level framework to explore gaps and deficiencies in how libraries currently address information poverty. He concludes with suggestions of how libraries might improve their approaches across these three levels. McKeown brings to the topic both experience as a public librarian and research and theoretical experience as a graduate student at Ulster University, having left his public library career in 2008 to get his Ph.D. at Ulster University.

This book is a reworking of McKeown's dissertation and includes his own firsthand experiences as a Public Librarian in Northern Ireland. McKeown conducted both qualitative and quantitative research on information poverty to establish a three-level theoretical framework: the macro (strategic), meso (community), and micro (individual). Those familiar with information poverty research will recognize this framework from the work of Yu (2006) and Thompson (2006) who have influenced McKeown's work. While McKeown borrows from earlier models, his work is exceptional because he applies it to public libraries but also because of the diverse scope of his research population: he includes library employees, managers, policymakers, users and nonusers in his research population. He aptly identifies the exclusion of nonusers from previous research and discussion, and he attempts to alleviate that absence in his work.

Taking a complex and multifaceted approach to defining information poverty, McKeown builds on the work of Chatman (1991, 1996, 1999) and Britz (2007) in moving our understanding of this contested term into a broad and multidimensional framework. Quoting a variety of researchers in the field, McKeown explains that the information divide is not only that which exists between the haves and the have nots but also between those who know where to find information and those who do not, and perhaps most importantly because so often ignored, those who recognize how information can help them and those who do not. McKeown argues that looking at information poverty in binary terms ignores the complexity of the concept: we must also include access, skills, capacity and use. Information poverty, according to McKeown, is the result of social, political, economic, cultural, personal, historical, educational and cognitive factors; each of which McKeown discusses. He also spends several pages looking at barriers to information access that move past simple factors of geography or the inability to

get to a library. Survey data is used to examine the important question of how people's attitudes about libraries also get in the way of their access. This focus on attitudes as barrier is a needed move beyond the more usual barriers of physical and economic access. 
McKeown establishes the extensive history of libraries fulfilling a social services role as a foundational reason for why libraries today should be interested and involved in alleviating information poverty. He connects the discussion of information poverty and its consequences with interviews and quotes from his research materials, giving what could be a dry discussion a human perspective.

McKeown describes his three-dimensional framework for information poverty. At the macro level, information poverty is an ethical issue that should be addressed by social institutions, in this case by library services; at the meso level he focuses on community attitudes and behaviors towards and about information that constrain local access; and at the micro level, he focuses on the intellectual, educational and attitudinal behaviors and skills that increase information poverty.

McKeown first examines the history and extensive discussion of information poverty in the literature, then develops indicators to measure information poverty in a community, and, finally, explores how public libraries use strategic policies, community engagement and literacy initiatives to address these issues. McKeown documents the importance of measuring information poverty to provide a baseline from which future programs can be evaluated. He suggests both a qualitative and quantitative approach to measuring information poverty that focuses on his three-factor model: measurements should look at personal, community and system wide factors. His framework explores these factors across each category. This framework could be useful to any public library attempting to define and measure information poverty, and it was satisfying to see a copy of the framework in the appendix.

McKeown discusses his data collection for each level of his model, explaining how he used a variety of measures including questionnaires, surveys, focus groups and interviews. McKeown weaves this data throughout the book's chapters to demonstrate how information poverty is created and maintained and which library services can address these issues. McKeown concludes the study with potential solutions for each level of the framework. A couple of solutions stand out: people need to be engaged by the library over and above providing "information services" that most people can access at home. Also, people need to feel like the library is there for them; McKeown's research suggests that many simply do not feel welcome or that the library meets their particular information needs. Attending to this barrier of access is apt given the limited focus user (and nonuser) attitudes have received as a reason people do not use their libraries.

Unfortunately, while McKeown's recommendation sections address multiple areas of deficit, he does not identify specifically how libraries might solve them. McKeown only suggests macro level strategies, such as: libraries need to understand communities better, do better marketing and promotion, and increase outreach. However, the real question is, how do libraries incorporate outreach to address the needs of the nonuser that McKeown so adeptly identifies? An interested reader might seek out some of the outreach research coming out of Canada for more specific suggestions including Campbell (2005) and Williment (2009) and the recent book, Linking Literacy and Libraries in Global Communities that includes chapters on outreach ideas (Asselin \& Doiron, 2016). 
McKeown's book is an excellent look at the three-level model of information literacy in an actual diverse, underfunded public library system though some will find the details of Northern Ireland a distraction. McKeown does spend extensive time on establishing the economic and information poverty of Northern Ireland and why the government has a responsibility to fund library literacy programs. Northern Ireland has high unemployment and a low overall use of the library rate, characteristics that might not fit many public library systems. McKeown notes that in Great Britain in general, library use rates are decreasing. However, a recent North American report suggests the contrary in the United States and Canada where library use is either increasing or remains stable (Reid, 2016). Clearly, every library system will not resemble that of Northern Ireland's, but McKeown's discussion is interesting and insightful for those looking for an understanding of information poverty.

McKeown's wide ranging discussion is accessible and useful for librarians in the public library system grappling with issues of information poverty. Students and librarians will both benefit from McKeown's excellent historic look at libraries and their relationship to information poverty. The early chapters are a concise introduction to information poverty. McKeown also includes an appendix of his interviews, survey questions, Information Poverty Indicators, and how these indicators fit with his three-level framework.

For library professionals and students hoping to develop a broad based understanding of information poverty, McKeown's book is an excellent introduction. The author's source material provides a full and contemporary overview on the theoretical and research background on this topic, particularly for sources outside of North America. One only wishes that McKeown might have provided more practical, battle-tested ideas for how to accomplish his long list of recommendations.

\section{References}

Asselin, M., \& Doiron, R. (2016). Linking literacy and libraries in global communities. New Jersey: Routledge.

Britz, J. (2007). A critical analysis of information poverty from a social justice perspective. (Doctoral Dissertation, University of Pretoria). Retrieved from http://repository.up.ac.za/bitstream/handle/2263/26468/Complete.pdf?sequ ence $=6$

Campbell, B. (2005). 'In' vs. 'with' the community: Using a community approach to public library services. Information for Social Change, 22. Retrieved from http://www.libr.org/isc/issues/isc22/22-2b.pdf

Chatman, E. A. (1991). Life in a small world: Applicability of gratification theory to information-seeking behavior. Journal of the American Society for Information Science, 42(6), 438-449. doi:10.1002/(SICI)10974571(199107)42:6<438::AID-ASI6>3.0.CO;2-B

Chatman, E. A. (1996). The impoverished life-world of outsiders. Journal of the American Society for Information Science, 47(3), 193-206. doi:10.1002/(SICI)1097-4571(199603)47:3<193::AID-ASI3>3.0.CO;2-T 
Chatman, E. A. (1999). A theory of life in the round. Journal of the American Society for Information Science, 50(3), 207-217. doi:10.1002/(SICI)10974571(1999)50:3<207::AID-ASI3>3.0.CO;2-8

Reid, I. (2016). The 2015 public library data service statistical report: Characteristics \& trends. Public Libraries, 55(3). Retrieved from http://publiclibrariesonline.org/2016/06/featurethe-2015-public-librarydata-service-statistical-report-characteristics-trends/.

Thompson, K. (2006). Multidisciplinary approaches to information poverty and their implications for information access. (Doctoral Dissertation, Florida State University). Retrieved from http://diginole.lib.fsu.edu/islandora/object/fsu:175942/datastream/PDF/vie $\underline{\mathrm{W}}$

Williment, K. (2009). It takes a community to create a library. Partnership: The Canadian Journal of Library and Information Practice and Research, 4(1). https://doi.org/10.21083/partnership.v4i1.545

Yu, L. (2006). Understanding information inequality: Making sense of the literature of the information and digital divides. Journal of Librarianship and Information Science, 38(4), 229-252. doi:10.1177/0961000606070600. 